\title{
競合運動する刺激間で生ずる両眼視野闘争時 における眼球運動の計測と解析
}

\section{小 林哲生、加藤 和 夫（北海道大学電子科学研究所）}

Measurements and analyses of eye movements during binocular rivalry caused by two competitive moving gratings

Tetsuo Kobayashi, Kazuo Kato (Research Ins titute for Electronic Science, Hokkaido University)

\section{1. まえがき}

本研究では両眼視に固有の知覚過程の一つ である両眼視野闘争過程 ${ }^{1-4)}$ における知覚図形 の内的交替、すなわち特定の時刻に競合する 2 つの図形のいずれが知覚されており、どの時点 でその知覚図形が交替するのかを眼球運動に より客観的なデータとして抽出し、眼球運動に 基づいて决定した内的知覚交替をトリガとし て事象関連電位並びに自発脳波律動の分散(パ ワー) 変動 5,6 をを捉えるための基礎的検討を行っ たので報告する。

\section{2. 両眼視野闘争過程}

両眼視野䦔争過程とは左右眼に与えられる 視覚刺激の形や動きなどが互いに極端に異な り一つに融合出来ない場合に、各々の視覚刺 激が交互に知覚される過程であり、Crick博士 らが最近Nature誌等で盛んに主張したことに より、視覚的アウェアネスや意識を定量的に研 究することのできる稀少な現象であるとの考 えが受け入れられつつある”。

\section{3. 実験方法}

眼球運動の測定には、強膜反射法を用いた両 眼眼球運動検出器（竹井機器工業、TKK2901） を使用した。この検出器では角膜と強膜の反射 率の違いを利用して発光ダイオードからの赤 外光（ピーク波長 $940 \mathrm{~nm}$ 、光放射強度 約 $12 \mathrm{~mW} / \mathrm{sterad}$ ）の反射光量が眼球の動きによっ て変化するのを検出する。空間分解能は $0.1^{\circ}$

以下である。検出器の出力はパーソナルコンピ ユータとオンラインで結ばれており、各種のデ 一夕処理を行うことができる。

被験者は正常な視力を有する男性 4名であ り、眼球運動検出器を装着しヘッドホルダー により頭部を固定された状態でミラーステレ
オスコープを介して、スクリーン上の二つの 刺激図形を左右眼独立に注視する。

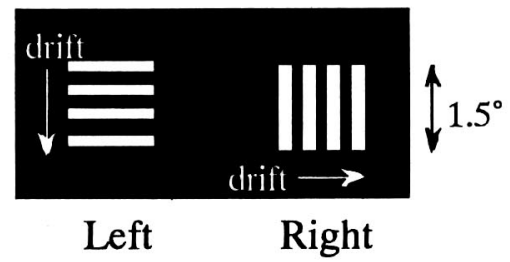

図 1 左右眼に独立に呈示した競合運動する 縞刺激の組みの一例。

実験に用いた刺激図形（図 1）は 4 本の縞 刺激（白 $25 \mathrm{~cd} / \mathrm{m}^{2}$ 、背景 $0.005 \mathrm{~cd} / \mathrm{m}^{2}$ ） である。 大きさは $1.5^{\circ} \times 1.5^{\circ}$ でありドリフト速度 $1.0^{\circ}$ 、 $1.5^{\circ} 、 2.0^{\circ} \mathrm{sec}$ の各条件下で左右の縞のドリ フトの向き（上下左右）の組み合わせを変え て眼球運動を計測した。データのサンプリン

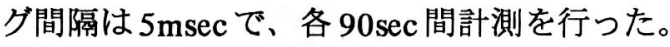
さらに対照実験として左右眼に同一刺激を 呈示した視野融合時における眼球運動の計 測も行った。

\section{4. 結果及び検討}

図 2 に視野融合時（a）および視野闘争時 （b）における眼球運動の水平方向成分の測定 結果の一例を示す。図に示した結果は視野融 合時については縦縞が右方向に $1.5^{\circ} \mathrm{sec}$ の速 度でドリフトした場合であり、視野闘争時に ついては縦縞が右方向、横縞が下方向にそれ ぞれに $1.5^{\circ} / \mathrm{sec}$ の速度でドリフトした場合で ある。図 2(a)から視野融合時には縦縞の右方 向のドリフトに追従するかたちで右方向へ の眼球運動が生じた後、サッケードで元に戻 るというのこぎり波的運動をすることが見 
て取れる。さらに視野融合した縞の左、上下 方向のドリフトに対してもドリフト方向へ の追従とサッケードの繰り返しというのこ ぎり波が観測された。この結果は被験者の知 覚が不随意の眼球運動に反映されることを 示唆していると考えられる。

次に視野闘争時における眼球運動を見る と、こぎり波運動の観測される時間と観測さ れない時間とが交互にみられることが分か る。この結果は視野闘争時における内的知覚 図形の交替を反映したものと推察されが、本 研究では被験者の主観による知覚図形の計 測を行っておらず、さらに刺激図形や呈示条 件を吟味することが今後の課題である。

\section{謝辞}

本研究の一部は財団法人 寿原記念財団の 研究助成によって行われたものであり謝意を 表する。

\section{参考文献}

1) R. Blake : A neural theory of binocular rivalry, Psychological Review, 96, 145-167, 1989.

2) T. Kobayashi: Psychophysical experiments and a neural network model of binocular rivalry, Frontiers of Medical and Biological Engineering, 4(1), 19-34, 1992.

3) I.P. Howard, and B.J. Rogers,: Binocular Vision and Stereopsis (Oxford Univ. Press, New York, 1995)

4) T. Kobayashi, et al.: Scalp dusitribution of the attenuated EEG rhythmic activities for dissimilar and/or moving images in binocular vision, Frontiers of Medical and Biological Engng., 7(2), 143-153, 1996.

5) G.Pfurtscheller,: Event-related synchronization (ERS): an electrophysiological correlate of cortical areas at rest. Electroenceph. clin. Neurophysiol., 83, 62-69, 1992.

6) 加藤和夫、小林哲生、栗城真也 : 視野闘争・融 合の 交替に伴う脳波リズム変動と事象関連電位, 医用電子と生体工学, 34(4), 8-16,1996.

7) F. Crick,: Visual perception: rivalry and consciousness. Nature 379, 485-486, 1996.

(a)

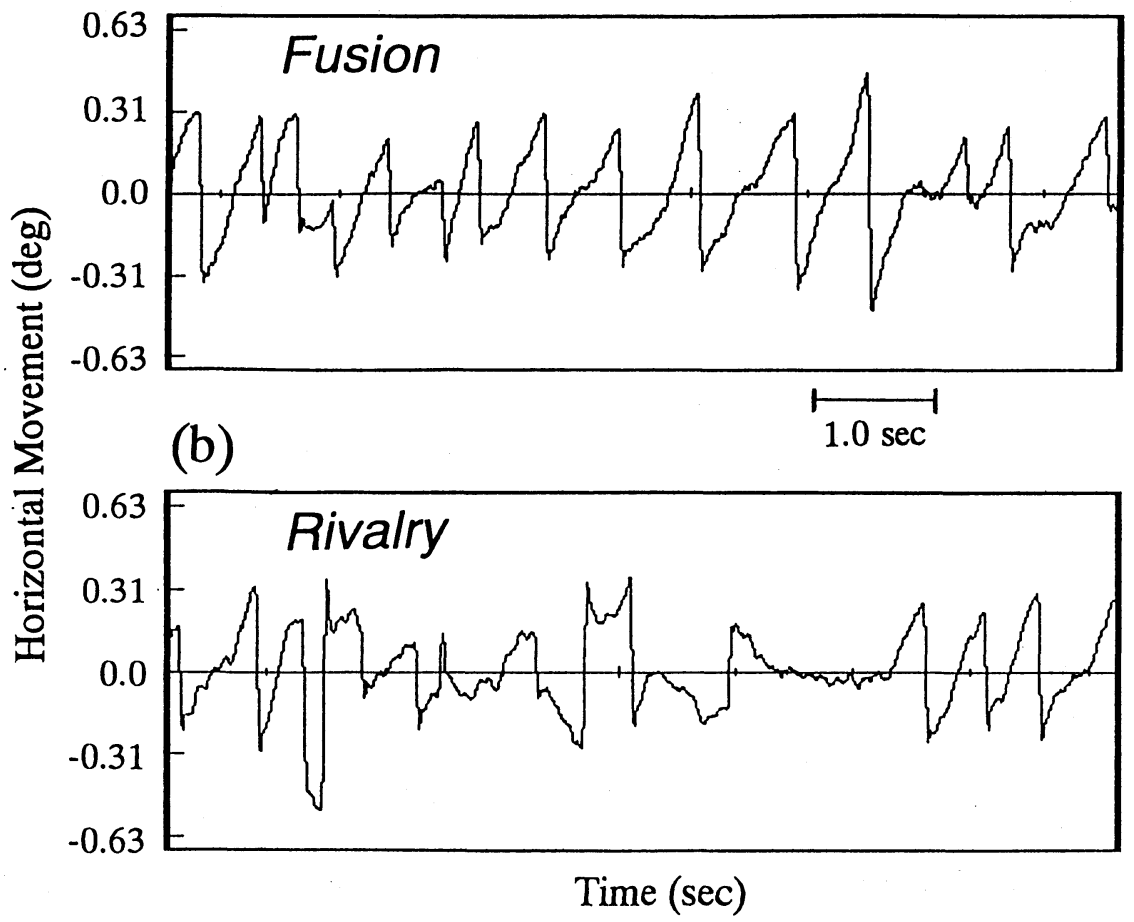

図 2 視野融合時 (a) および視野闘争時 (b) における眼球運動の水平方向 成分（被験者 MS）。縞のドリフト速度は $1.5^{\circ} \mathrm{sec}$ である。 